かに複ば向文るうびす信た

に以引箇れ発は顕自、こ仰、本

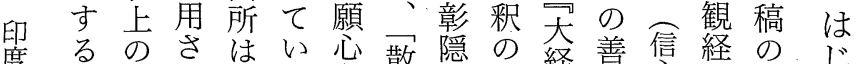

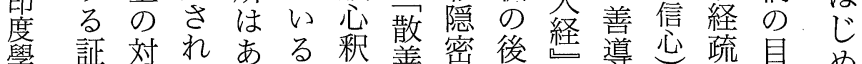

學文証対れてるる。勫善密後経導心䟽目め

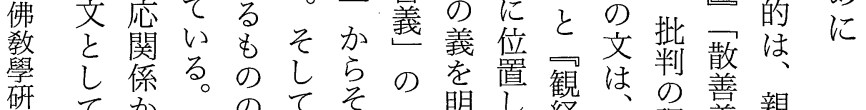

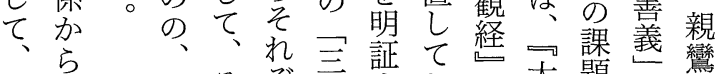

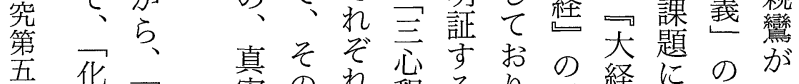

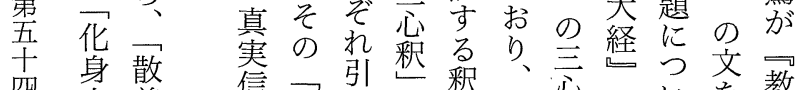

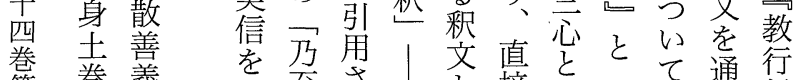

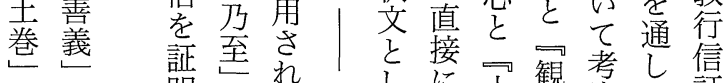

号との 明され、至て住察て証

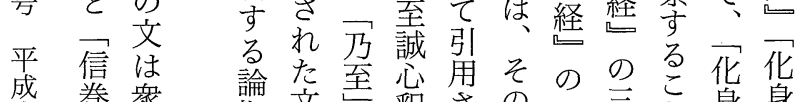

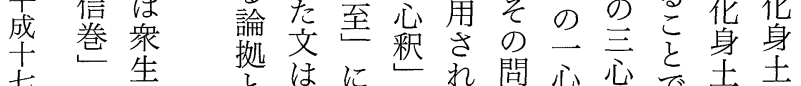

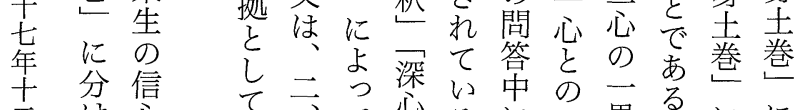

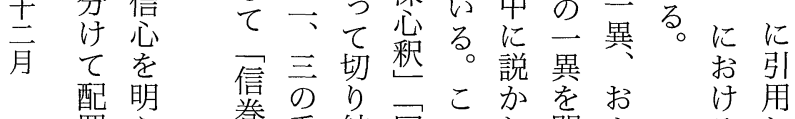

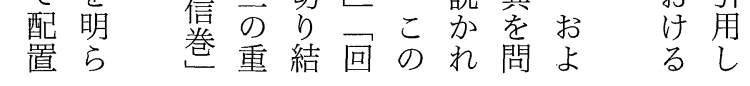

実四ま所六弥のに拈利ま 心事た為道陀中同よ真た の 等 随 の 等 仏にじび実真 中を喜善の抮く穢と実 のもせを自よ自、国言に 身つざ讃他び他我等う云 業てれ嘆依依凡も。をは種 に、とす正正聖ま制、あ 、彼な。の三等た作まり この りも王報の六した の阿。し 報を善く立云一 死陀た業悪嘆懃ご行あは

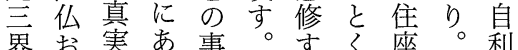
界お実 あ事。专々 座。利 等よ゙心 心 ら 自依中は、厭真実と一は 他正の身敬す。実心想切真二 の三身敬。心のう菩実に

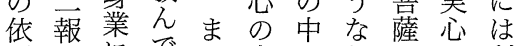
正をにでた中のりのの利 報養拿を切口業二悪に真 を掌を遠衆業ににを自実 軽。し遠生に、礼ざは制他な 慢ま礼ざ敬主三彼真捨のり 厭真し、れ、業界阿念貢悪 自

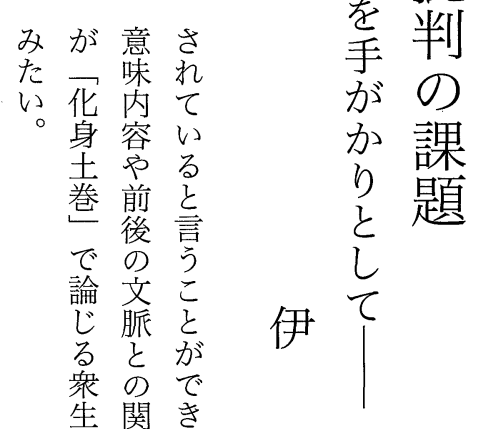

生 関き

の係よ

信をう

心 尋

のねと

問るこ

題こで 㤙

に

いよれ

て $っ$

考ての深

究、引

し 親 文

がの

課

と

東

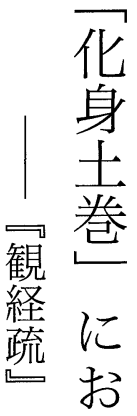

散け

善る

義 信

の仰

文批

手 判

て 彎の 
種後二の童闇を必に賤、憶三うょつ

あにに总意連を起ずはしそ念業とういこと。思捨

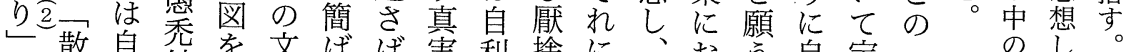

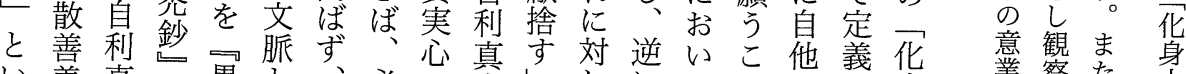
う義真下患々

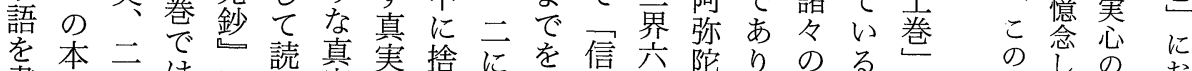

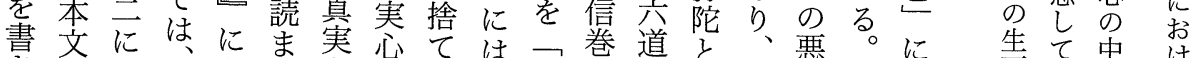

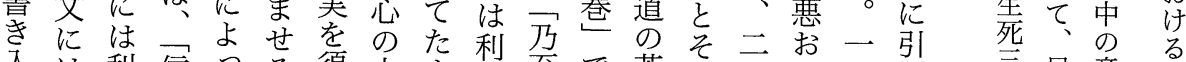
入は利信つる須中ま他至で莌のうょつ用晋目意信

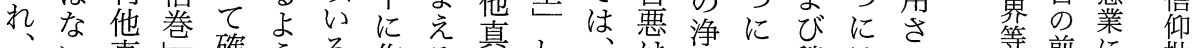

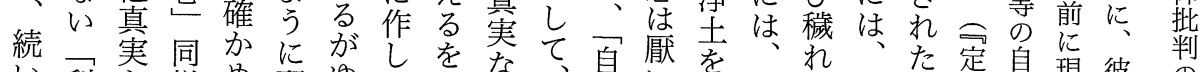

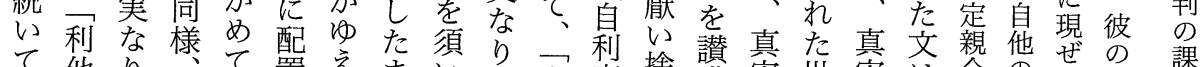

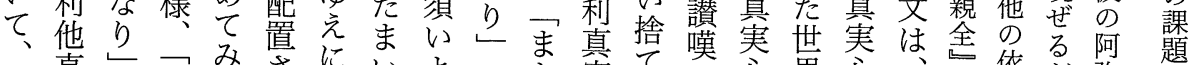

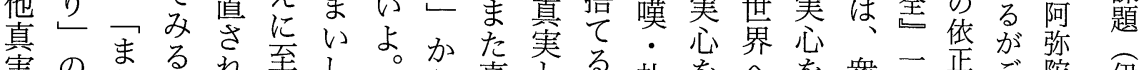

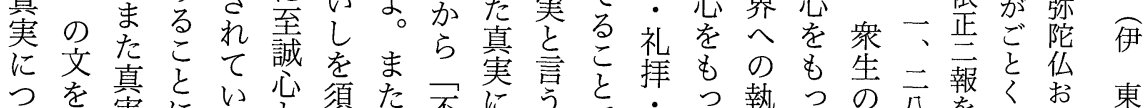

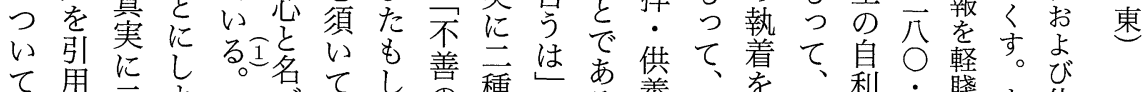

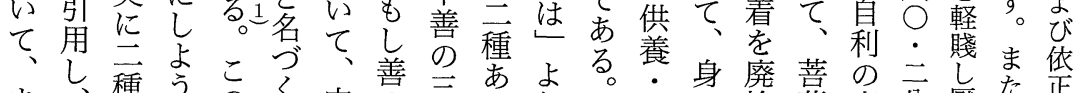

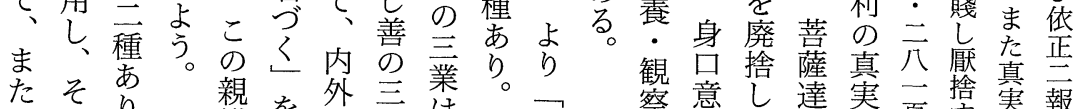

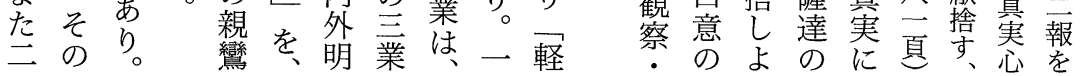

釈 军

の経深

後経 深

○と积

䶊隺 は

に経烄 釈

机穴

ぞ学経

机心

引と

捅劣観

机経経

て电

いのの

る。 咅

こ と

ご 嘼

注異 異

自を問お

た自び
にとる来れるで真

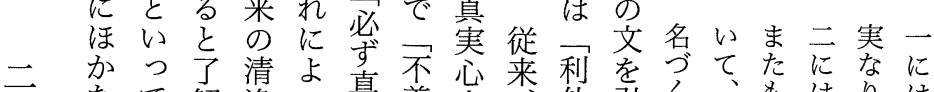

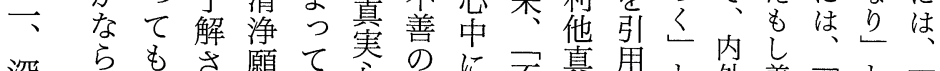

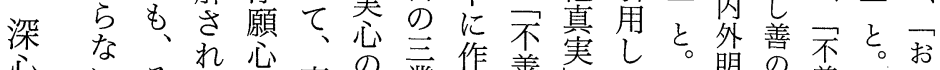

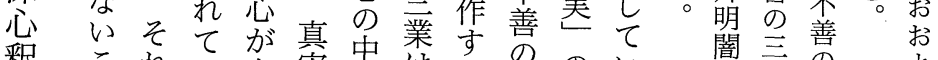

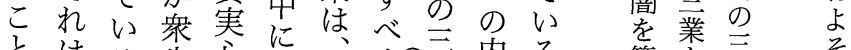

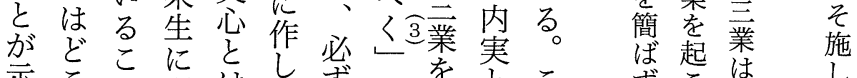

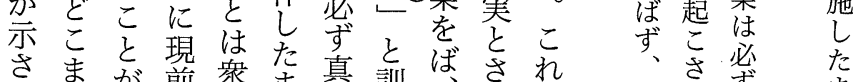

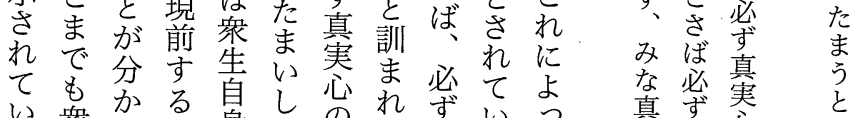

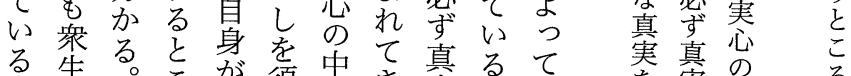

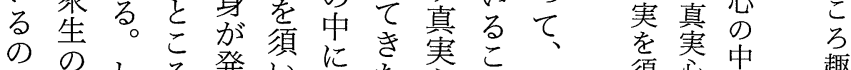

でしろ発い㨒た灾市不須心虫趣

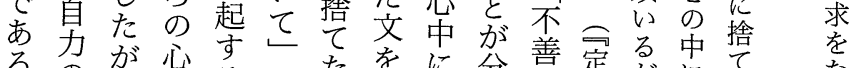

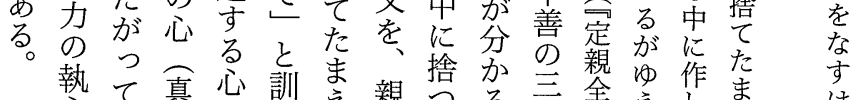

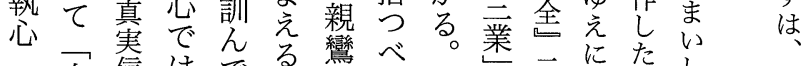

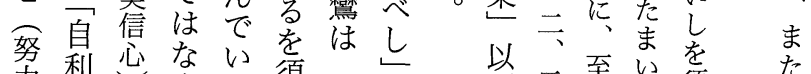
努利心ない須信意真でる。高誠し須 な 識実あ如こよ巻ず文頁灾須よ。真 
右り彼善口口問で経う籍こ立念経じ問の

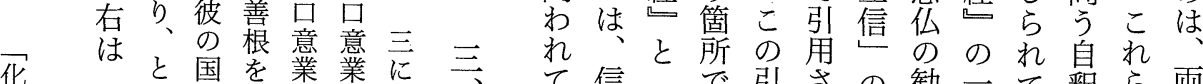

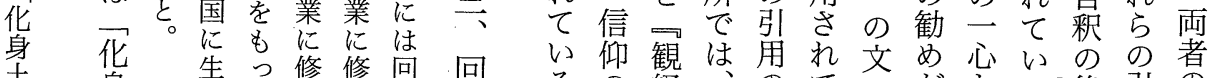

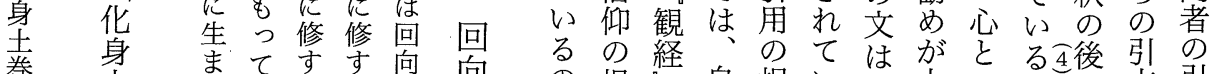

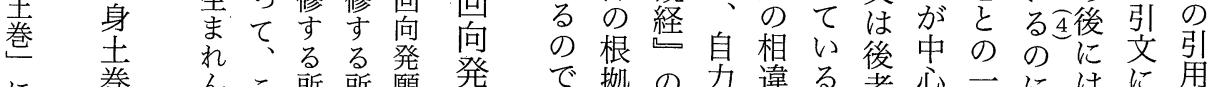
に巻 んこ所所願発願で拠の力違る者心二ににに用

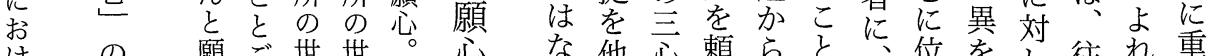

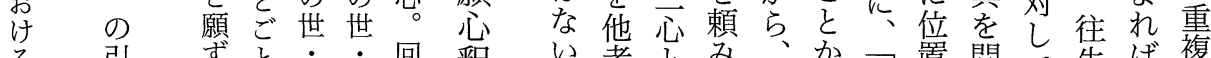

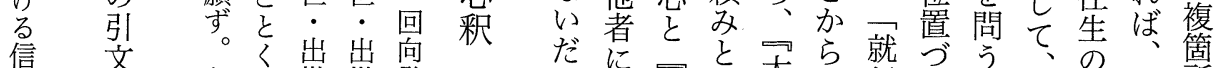

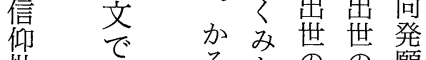
批 あ るなの願

判るが真善善心

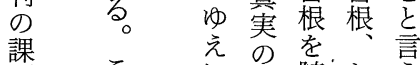

題ここに深随おう

伊 ご定向信喜よは 東は、全願心て、他過 回一心京中元招 向、名に自自切よ 発云名靣自 の 心三るし所聖生 と頁なるて修 の

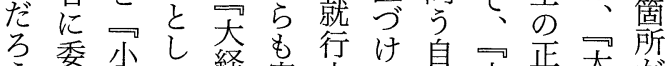

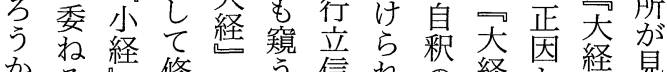
かる鉴子う信れの経と経見

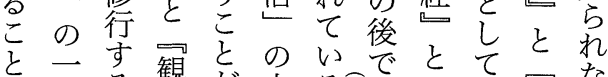

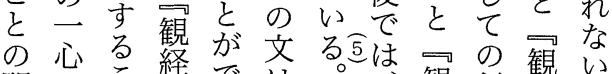
問とこ経では。観行観い 題のとのき前こ釈経の経と 性異問志う。にこ者の迦匹簡のう

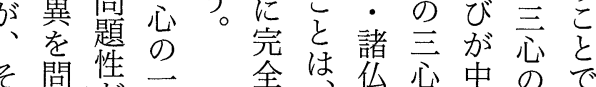

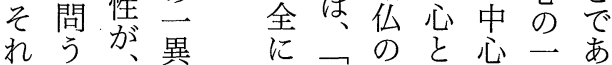
ぞ箇口分就称尼異る れ所大問け人名小論を

衆高で努往如訓必に至須生てしてなのは

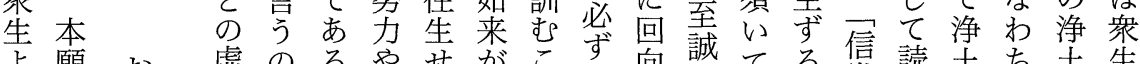
よ願打虚のるやせ怔こ向誠て る信読土ち、土生

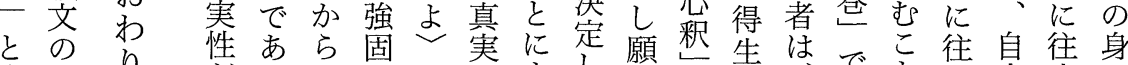

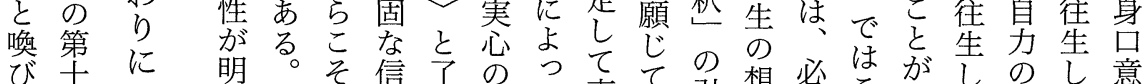

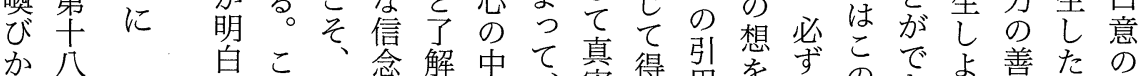

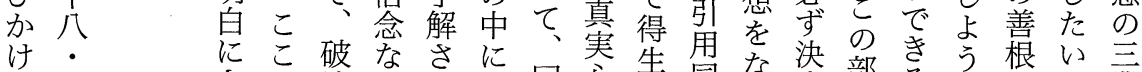

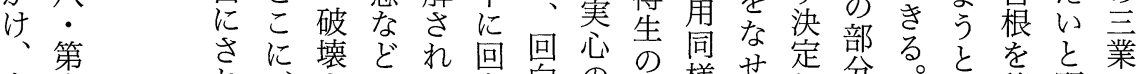

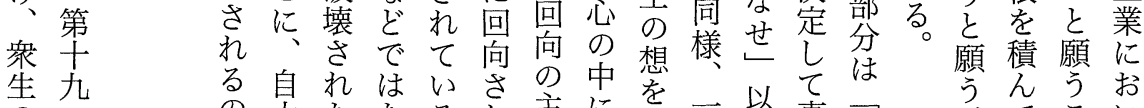

の.

救 第

済 云

を †

願 願

わは

れ我

い夕

る。衆

に

か

之方
の゙をたなる。体回作般降真乃

あも退、つ本を向す般降実至

ろつ転如ま願阿しべに文

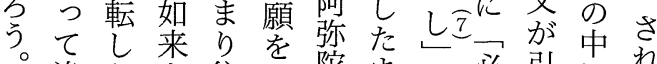

浄たよ往も陀ま子必引にれ

土り り 生ち転方訓須さ用回

のす回の い転る愌願ま根る る

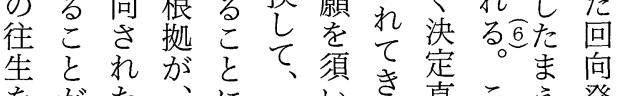

をがた、に、いた真こえ発

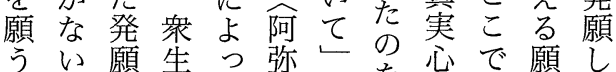

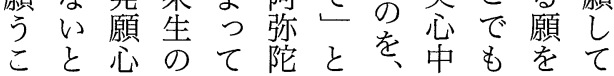

、でこい

行者そ它修

のれあ め

努をるた

力差美善

意し 定根

識向義を

けさも

自るれつ

力こてて

執とい

心にる阿

とうす陀 

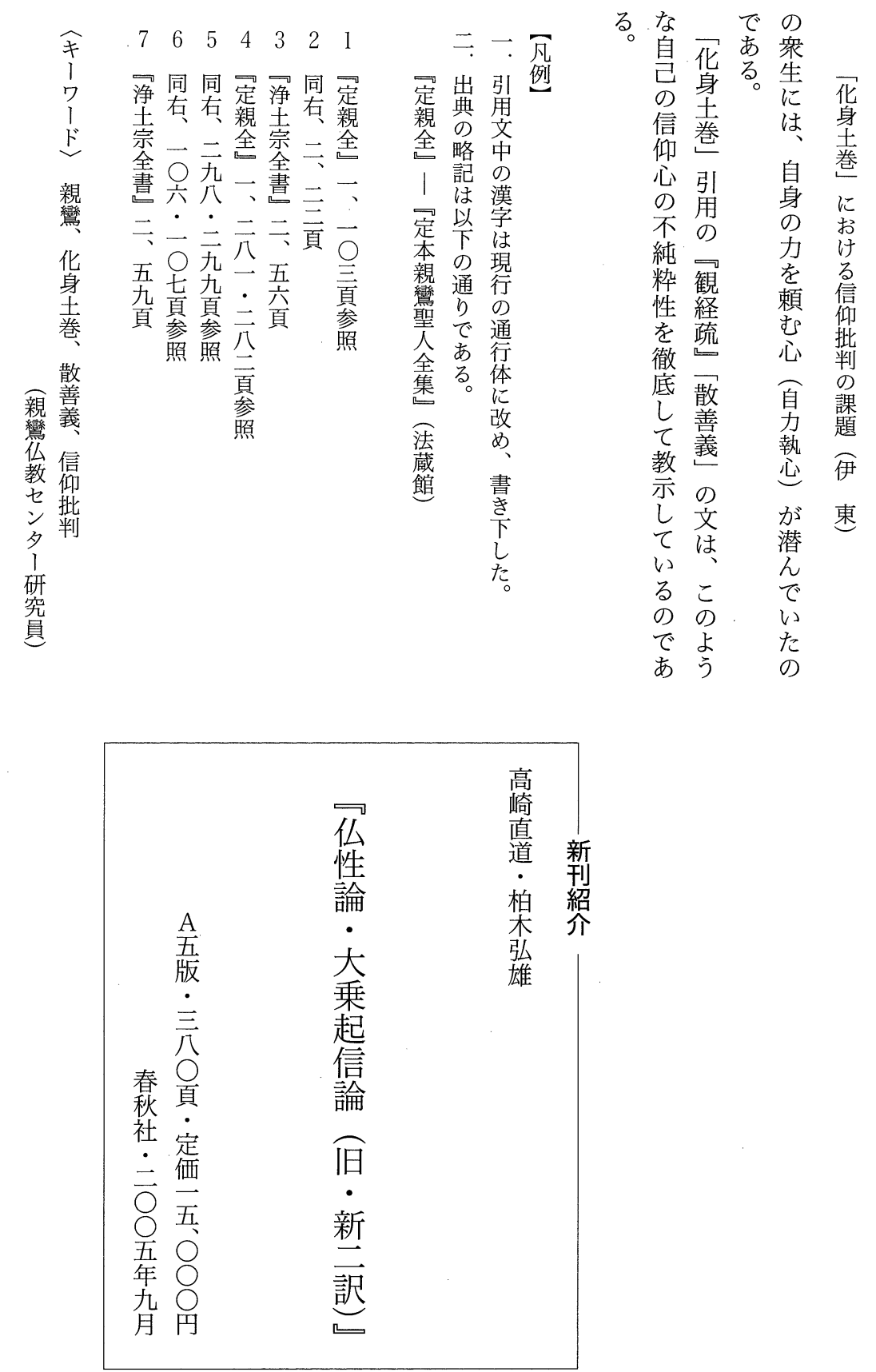
states:

The person who lives true shinjin, however, abides in the stage of the truly settled, for he has already been grasped, never to be abandoned. There is no need to wait in anticipation for the moment of death, no need to rely on Amida's coming. At the time shinjin becomes settled, birth too becomes settled (Letters of Shinran, Hongwanji International Center, 1978: 20)

Shinran emphasizes that there is no need to rely on Amida's coming at the moment of death. In this passage we can find that Shinran made clear the truth of salvation in the present life. This change of salvation's time - from the moment of death to the present life - is Shinran's idea of the change of time.

39. The Criticism of Faith in the Chapter on the Transformed Buddha-Bodies and Lands: With reference to the Chapter of Non-Meditative Practice in the Commentary on the Contemplation Sütra

Eshin ITŌ

This essay intends to discuss the subject of the criticism of faith through Shan-tao's treatment in the "Chapter of Non-meditative Practice" which Shinran quoted in the "Chapter of the Transformed Buddha-Bodies and Lands" of the Kyogyyōshinshō. Hereby, I want to investigate the characteristic or the difference of faith of all creatures that Shinran clarified in the "Chapter of the Transformed Buddha-Bodies and Lands."

\section{On Compassion in the Fourth Passage of the Tannishō}

Toshiaki MIHARU

The Japanese phrase, Kono jihi shijünashi in the fourth passage of the Tannishō, has been understood to mean that our compassion is not throughgoing. But in my opinion it means that it is endless. Tannishō collects Shinran's sayings. By reading this book, we understand that Shinran is a man of compassion. 